\title{
Bence Jones Proteins and Light Chains of Immunoglobulins
}

\author{
XI. A TRANSIENT BENCE JONES-RELATED PROTEIN ASSOCIATED \\ WITH CORTICOSTEROID THERAPY
}

\author{
Alan Solomon, Carla L. Mclaughuin, and J. Donald Capra \\ From the University of Tennessee Memorial Research Center and Hospital, \\ Knoxville, Tennessee 37920, and the Department of Microbiology, University of \\ Texas Southwestern Medical School, Dallas, Texas 75235
}

\begin{abstract}
A B S T R A C T Urine specimens from patients with multiple myeloma and Bence Jones proteinuria frequently contain low molecular weight proteins which correspond either to the amino-terminal, variant half $\left(V_{L}\right)$ or to the carboxyl-terminal, constant half $\left(C_{L}\right)$ of the Bence Jones protein. Analyses of urine specimens from such patients who had received high doses of corticosteroids as part of their treatment regimen revealed that concomitantly with a decrease in Bence Jones protein excretion was the appearance of a low molecular weight protein related to the Bence Jones protein but not identical to the $V_{L}$ or to the $C_{L}$.

Analyses of daily urine specimens obtained from one such patient over an extended time period revealed that a reproducible chain of events occurred during a treatment regimen which included oral administration of $75 \mathrm{mg}$ of prednisone daily for 7 consecutive days. The amount of Bence Jones protein excreted decreased progressively, and by the 5 th day was usually less than $10 \%$ of the pretreatment value. The urine specimen obtained on the 6th day of treatment was virtually devoid of Bence Jones protein but contained a newly appearing protein whose electrophoretic mobility was distinct from that of the Bence Jones protein or its $V_{\mathbf{L}}$ or $C_{\mathbf{L}}$. Cessation of corticosteroid therapy resulted in a prompt disappearance of the new protein and in a progressive increase in the amount of Bence Jones protein excreted.

The new protein was isolated from the urine of this patient and was purified for comparative studies with
\end{abstract}

This work was presented in part at the 66th Annual Meeting of the American Society for Clinical Investigation, Atlantic City, N. J., 5 May 1974 (J. Clin. Invest. 53: 77a).

Received for publication 21 June 1974 and in revised form 11 November 1974.

The Journal of Clinical Investigation Volume 55 March 1975·579-586
Bence Jones protein and with the $V_{L}$ and $C_{L}$ prepared by specific enzymatic cleavage of the Bence Jones protein. These studies revealed that the new protein was most related antigenically to the $C_{L}$, but could be distinguished immunochemically from the $C_{L}$. This new protein, a component found in vivo related to the constant half of the light polypeptide chain, was designated $\mathrm{C}_{\mathrm{L}} *$, and was structurally 25 amino acid residues longer than the $C_{L}$, that is, the amino-terminus of the enzymatically prepared $C_{L}$ was at position 117 whereas that of the transitory new Bence Jones-related protein was at position 92 of the light polypeptide chain.

Biosynthetic studies were performed with plasma cells derived from the bone marrow of this patient at a time when both the $\mathrm{C}_{\mathrm{L}}$ * and the Bence Jones protein were being excreted; both proteins were identified in extracellular culture fluid by immunochemical techniques. Whether the $C_{L} *$ is of synthetic or catabolic origin is presently not known; however, the detection of the $C_{2}$ * and the absence of any detectable protein related to the $V_{L}$ in the extracellular culture fluid might imply a synthetic origin of the $\mathrm{C}_{\mathrm{L}}{ }^{*}$ and suggest a corticosteroidinduced alteration in light chain synthesis.

\section{INTRODUCTION}

Proteins of molecular weight lower than Bence Jones proteins, but antigenically related to Bence Jones proteins, have been detected in the urine specimens from patients with multiple myeloma and Bence Jones proteinuria, as well as in urine of normal individuals (17). Immunochemical and structural comparisons of the smaller urinary components with the homologous Bence Jones protein have revealed a more frequent corre- 


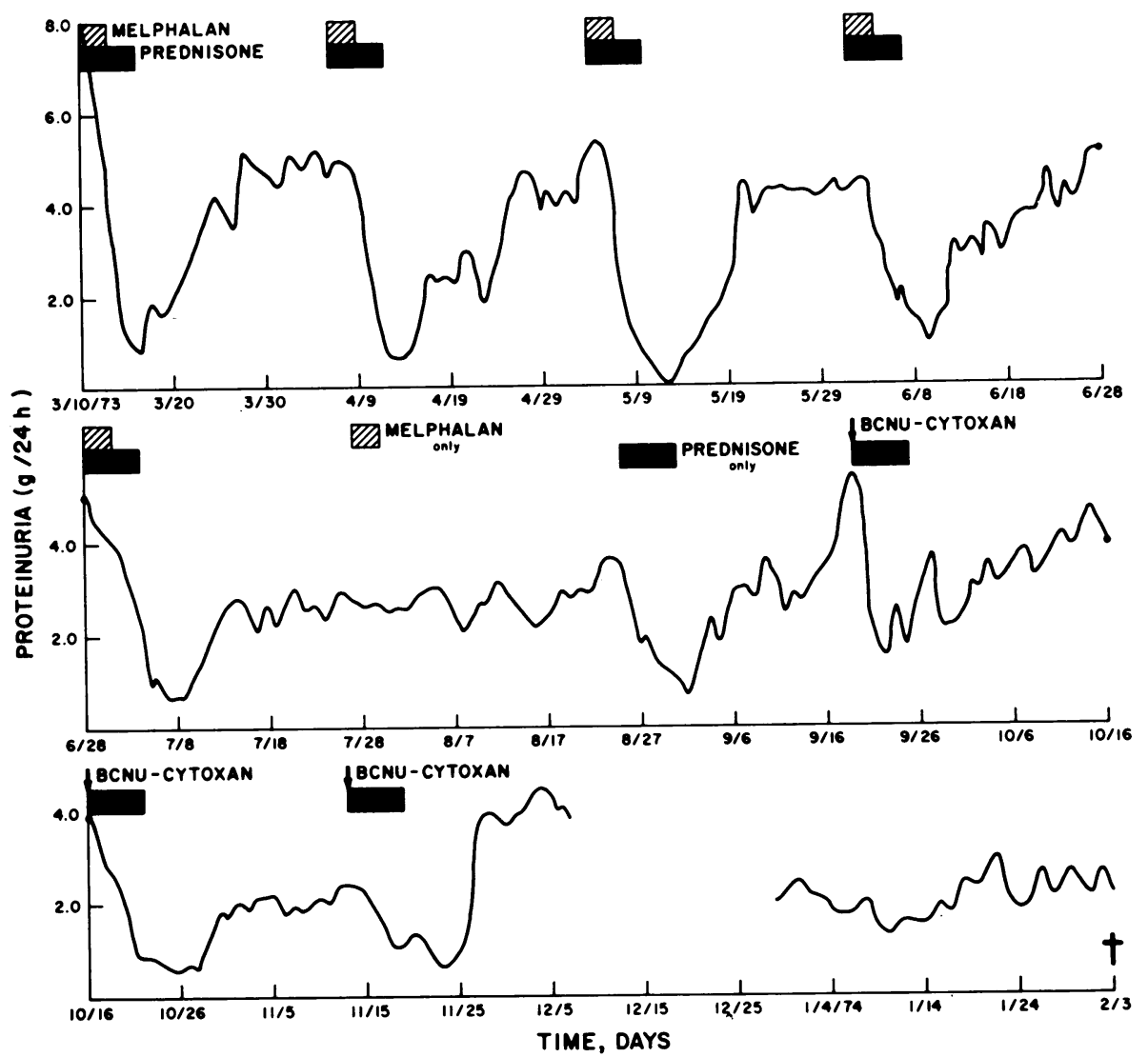

FIGURE 1 Therapy-induced alteration in urinary protein of a patient with multiple myeloma and Bence Jones proteinuria. The amount of daily $24-\mathrm{h}$ urinary protein excreted during an 11-mo period is presented graphically, and the treatment schedules are indicated as follows: solid bar, prednisone, $75 \mathrm{mg}$, given orally for 7 consecutive days; hatched bar, melphalan, $14 \mathrm{mg}$, given orally for 4 consecutive days; arrow, 1,3-bis (2-chloroethyl)-1-nitrosourea, 130 $\mathrm{mg}$, and cyclophosphamide (Cytoxan), $680 \mathrm{mg}$, given i.v. on the 1st day of prednisone therapy. The gap in the graph represents a period of time during which the patient underwent surgery and complete urine collections could not be obtained.

spondence to the amino-terminal, variant half $\left(V_{L}\right)^{1}$ than to the carboxyl-terminal, constant half $\left(C_{L}\right)$ of the light polypeptide chain $(2-6,8,9)$. The occurrence of $V_{L}$ or $C_{L}$ in urine has no dependence on the antigenic type of the Bence Jones protein, the degree of proteinuria, or the status of renal function. These urinary components may result from catabolic $(10,11)$ or synthetic (11-15) processes.

Recently, we have observed that urine specimens from patients with multiple myeloma who have received high doses of corticosteroids as part of their treat-

${ }^{1}$ Abbreviations uscd in this paper: $\mathrm{C}_{\mathrm{L}}$, carboxyl-terminal, constant half of the light polypeptide chain; $\mathrm{C}_{\mathrm{L}}{ }^{*}$, component found in vivo related to the constant half of the light polypeptide chain; $\mathrm{C}_{\mathbf{L}} \mathbf{P}$, constant half of peptic cleaved light polypeptide chain; $V_{L}$, amino-terminal, variant half of the light polypeptide chain; $\mathrm{V}_{\mathbf{L}}^{\mathbf{P}}$, variant half of peptic cleaved light polypeptide chain. ment regimen contain a low molecular weight protein related to the Bence Jones protein but not identical to either the $V_{L}$ or the $C_{\mathbf{L}}$. The results of detailed studies on one patient from whom daily urine collections were obtained for a period of almost $1 \mathrm{yr}$ are presented herein.

\section{METHODS}

Urine specimens were collected without preservative and were maintained at $0^{\circ}-4^{\circ} \mathrm{C}$ throughout the 24 - $\mathrm{h}$ collection period. Subsequently, a sample of each $24-\mathrm{hr}$ specimen was stored frozen at $-20^{\circ} \mathrm{C}$ or $-70^{\circ} \mathrm{C}$. The remaining sample was dialyzed extensively at $4^{\circ} \mathrm{C}$ in $23 / 32$ Visking tubing (Union Carbide Corp., New York) against deionized, double-distilled water and then lyophilized. For analytical purposes the dried urinary proteins were reconstituted in water to a concentration of $20 \mathrm{mg} / \mathrm{ml}$.

The protein concentration of the urine specimens was determined by a sulfosalicylic acid turbidity method. 0.2 $\mathrm{ml}$ of urine was mixed with $1.5 \mathrm{ml}$ of $4 \%$ sulfosalicylic 

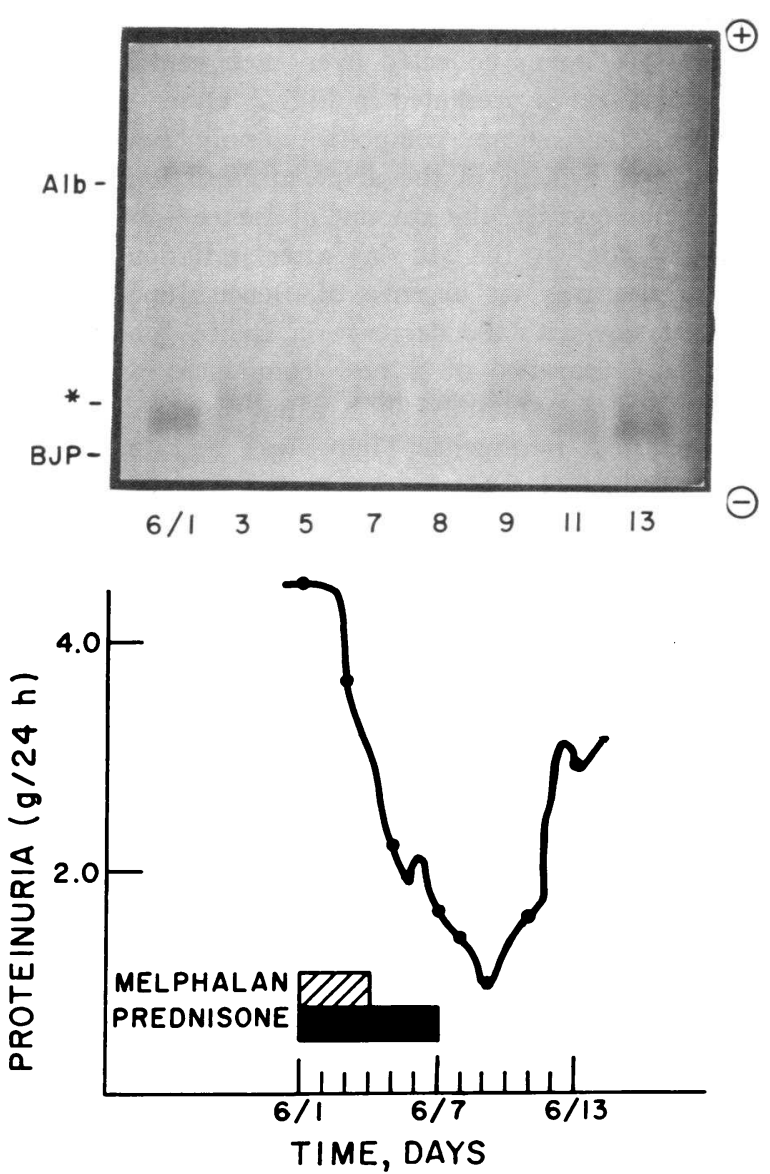

FIGURE 2 Analyses by cellulose acetate electrophoresis of urine specimens obtained over one cycle treatment with melphalan and prednisone. A graph of the amount of protein excreted daily during this period is presented. The positions of albumin (Alb), Bence Jones protein (BJP), and the new component $\left(^{*}\right)$ in the electropherogram are as indicated.

acid and incubated at $37^{\circ} \mathrm{C}$ for $15 \mathrm{~min}$ before the reading of optical density, at $650 \mathrm{~nm}$, against a saline-sulfosalicylic acid blank. The protein concentration was determined from a standard plot of optical density of protein solutions of known concentration. The protein concentration of isolated Bence Jones proteins or components was determined by a modification of the Folin-Ciocalteu method (16).

Isolation of immunoglobulin components was achieved by zone (block) electrophoresis (17) and further purified by gel filtration through P100 polyacrylamide (Bio-Rad Laboratories, Richmond, Calif.) $2.5-\times 100-\mathrm{cm}$ columns. The eluting buffer was $0.15 \mathrm{M} \mathrm{NaCl}, 0.005 \mathrm{M}$ Tris- $\mathrm{HCl}, 0.001 \mathrm{M}$ EDTA, and $0.003 \mathrm{M}$ sodium azide, $\mathrm{pH}$ 7.6.

The methods for peptic cleavage of Bence Jones protein into its variant half and constant half were as described elsewhere (11).

Immunoelectrophoresis and immunodiffusion analyses as well as preparation of antisera were as previously described (18).

Cellulose acetate electrophoresis was performed on a Microzone apparatus (Beckman Instruments, Inc., Palo
Alto, Calif.). Optimum resolution was obtained by electrophoresis for $40 \mathrm{~min}$ in 0.075 ionic strength barbital buffer, $\mathrm{pH}$ 8.6. Visualization of the protein bands after ponceau $\mathrm{S}$ staining was enhanced by keeping the membrane opaque, i.e., destaining with 5\% acetic acid and drying without further treatment.

Starch gel electrophoresis in alkaline- $8 \mathrm{M}$ urea-mercaptoethanol (0.05 M glycine, $0.006 \mathrm{M} \mathrm{NaOH}, 0.1 \mathrm{M}$ 2-mercaptoethanol, $\mathrm{pH}$ 9.3) was performed as previously described (19).

Biosynthetic studies with bone marrow obtained in a heparinized syringe by aspiration from the posterior iliac crest of the patient were performed as previously described (11).

Amino acid sequence analyses were performed on a Beckman model 890C automated sequencer (Beckman Instruments, Inc., Palo Alto, Calif.) using methods as previously described (20). The phenylthiohydantoin derivatives were identified by thin layer chromatography, gas chromatography, or after acid hydrolysis by an amino acid analyzer (20).

\section{RESULTS}

In order to ascertain the response to therapy we measured the amount of protein in daily urine specimens

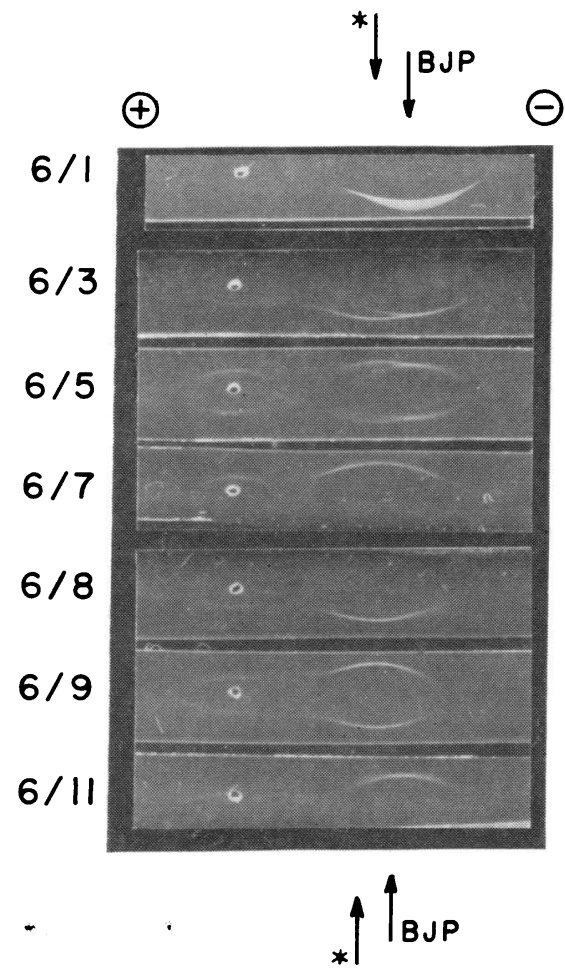

FIGURE 3 Immunoelectrophoretic analyses of urine specimens obtained during one treatment cycle. The antiserum troughs contained an antiserum prepared against the patient's Bence Jones protein. The positions of the precipitin arc of the Bence Jones protein (BJP) and the new component $(*)$ are indicated. The precipitin arcs adjacent to the antigen wells represented partially denatured, intact Bence Jones protein. 


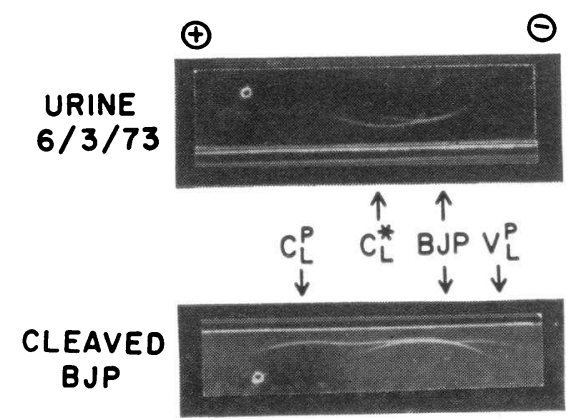

FIgURE 4 Immunoelectrophoretic comparison of the new constant half-related component $\left(\mathrm{C}_{\mathrm{L}}{ }^{*}\right)$ contained in a urine specimen obtained $48 \mathrm{~h}$ after initiation of treatment with that of the constant half $\left(\mathrm{C}_{\mathrm{L}}{ }^{\mathrm{P}}\right)$ and variant half $\left(\mathrm{V}_{\mathrm{L}}{ }^{\mathrm{P}}\right)$ produced in vitro by limited proteolytic cleavage of the Bence Jones protein (BJP). The antiserum troughs contained an antiserum prepared against the patient's Bence Jones protein. The precipitin arc adjacent to the antigen well which contained the urine specimen represented partially denatured, intact Bence Jones protein.

collected from patients with multiple myeloma and Bence Jones proteinuria. It was noted that the amount of protein in urine specimens from certain patients, who were receiving corticosteroids as a part of the treatment regimen, decreased markedly but returned to pretreatment level with cessation of therapy. Through detailed studies this phenomenon was elucidated in one patient from whom we had obtained consecutive daily urine collections for a period of almost $1 \mathrm{yr}$.

A graph of the total urinary protein excreted daily by a 54-year old female with multiple myeloma and Bence Jones proteinuria is shown in Fig. 1. As evident from the graph, a reproducible chain of events occurred during the treatment regimen which included daily administration of $75 \mathrm{mg}$ of prednisone given as one dose orally for 7 consecutive days in conjunction with cytotoxic chemotherapy which initially consisted of melphalan, $8 \mathrm{mg} / \mathrm{m}^{2}$, given orally for 4 days, and subsequently, 1,3-bis(2-chloroethyl)-1-nitrosourea, $75 \mathrm{mg} /$ $\mathrm{m}^{2}$, and Cytoxan, $400 \mathrm{mg} / \mathrm{m}^{2}$, given i.v. on the 1 st day of corticosteroid treatment. With each treatment cycle, there was a marked decrease in proteinuria which, by the 5th day, was usually less than $10 \%$ of the pretreatment value. The next 7-14-day period was characterized by an increase in proteinuria approaching the pretreatment value. That the marked decrease in proteinuria was associated with corticosteroid treatment and not with the alkylating agent was evidenced by the fact that treatment with melphalan alone had no effect on the amount of protein excreted, whereas administration of prednisone alone produced the marked decrease in proteinuria.

To establish that the decrease in proteinuria indeed reflected a decrease in Bence Jones proteinuria, we ex- amined by cellulose acetate electrophoresis the series of urine specimens collected over each complete cycle. One such cycle is presented in Fig. 2. Other than albumin and trace serum components, only Bence Jones protein was evident in the urine at initiation of treatment. Subsequently, the amount of Bence Jones protein decreased, and by the 5th day after initiation of treatment, there was an absence of Bence Jones protein. Simultaneous with the decrease in Bence Jones protein was the appearance of a new component which persisted for approximately $48 \mathrm{~h}$ after discontinuation of corticosteroid treatment. There was a rather abrupt disappearance of the new component concomitant with the reappearance of Bence Jones protein. The immunoelectrophoretic analyses of these urine specimens with an antiserum prepared against the patient's Bence Jones protein is shown in Fig. 3. Only whole Bence Jones protein was detected at the start of treatment. The intensity of the Bence Jones protein precipitin arc decreased after initiation of therapy, and at the same time a new component antigenically deficient to the Bence Jones protein appeared. By the 5th day after initiation of treatment, the urine specimen was virtually devoid of Bence Jones protein and only the new component was detected for the next 2 days. $48 \mathrm{~h}$ after treatment was discontinued, the new component was no longer detectable and the Bence Jones protein had reappeared. Furthermore, this component was evident only in urine specimens obtained during the periods when corticosteroids were part of the treatment regimen, i.e., it was not detected in urine specimens obtaind during the period when melphalan was given without concomitant administration of prednisone; these specimens were examined electrophoretically and immunochemically at a protein concentration of $20 \mathrm{mg} / \mathrm{ml}$.

From the immunochemical reactivity of the new component, it was obvious that this protein was related, but antigenically deficient, to the intact Bence Jones protein. Furthermore, that this component was antigenically related to the constant half of the Bence Jones protein was evidenced by the fact that absorption of the homologous antiserum with a heterologous $\kappa$-chain removed all reactivity with this new component.

The relationship between this constant half-related new component found in vivo, designated $\mathrm{C}_{\mathrm{L}}{ }^{*}$, and the constant half produced in vitro by proteolytic cleavage was determined by additional immunochemical studies (Fig. 4). Bence Jones protein was subjected to limited peptic digestion (11) so that the intact Bence Jones protein as well as constant half $\left(\mathrm{C}_{\mathbf{L}}^{\mathbf{P}}\right)$ and variant half $\left(V_{L}{ }^{P}\right)$ of the peptic cleaved light polypeptide chain were present. This sample was compared immunochemically with a urine specimen containing the $\mathrm{C}_{\mathrm{L}}$ * as well as the intact Bence Jones protein. A difference 
in the net charge of $\mathrm{C}_{\mathrm{L}}{ }^{\mathrm{P}}$ and $\mathrm{C}_{\mathrm{L}}$ * was clearly evident from the precipitin reactions. The $C_{L}{ }^{*}$, isolated by zone electrophoresis and purified by gel filtration, was subjected to alkaline-urea starch gel electrophoresis; the mobility of $\mathrm{C}_{\mathrm{L}}{ }^{*}$ was distinct from that of the isolated $\mathrm{C}_{\mathbf{L}}{ }^{\mathbf{P}}, \mathrm{V}_{\mathbf{L}}{ }^{\mathbf{P}}$, or Bence Jones protein (Fig. 5). The isolated $C_{L}{ }^{*}$ was also compared with the $C_{L}{ }^{P}$ by immunodiffusion analyses in which antisera prepared against the Bence Jones protein and against the $\mathrm{C}_{\mathrm{L}}{ }^{*}$ were utilized. No antigenic distinction between the $\mathrm{C}_{\mathrm{L}}{ }^{*}$ and $\mathrm{C}_{\mathbf{L}}{ }^{\mathbf{P}}$ was evident with the antiserum prepared against the whole Bence Jones protein; however, the $\mathrm{C}_{\mathrm{L}}{ }^{\mathrm{P}}$ was antigenically deficient to the $\mathrm{C}_{\mathrm{L}}{ }^{*}$ with the anti- $\mathrm{C}_{\mathrm{L}}{ }^{*}$ antiserum.

Amino acid sequence analyses of the isolated $C_{L}{ }^{P}$ and $\mathrm{C}_{\mathrm{L}} *$ were performed. The amino-terminal sequence of the $\mathrm{C}_{\mathbf{L}}{ }^{\mathrm{P}}$ was homologous with the sequence of the $\kappa$ light polypeptide chain beginning at position 117 in the constant half, i.e. Ile-Phe-Pro-Pro, etc., as previously noted by Seon, Grossberg, Roholt, and Pressman (21). The sequence of the first 28 amino acid residues of the $\mathrm{C}_{\mathrm{L}} *$ was Asp-Ile-Phe-Pro-Gly-Thr-PheGly-Gln-Gly-Thr-Lys-Val-Glu-Ile-Lys-Arg-Thr-ValAla-Ala-Pro-Ser-Val-Phe-Ile-Phe-Pro. This sequence includes the entire variable region of the $C_{L} *$ and extends 13 residues into the constant region. By homology with the sequence of $\kappa$ light chains (22), the aminoterminus of the $\mathrm{C}_{\mathrm{L}} *$ corresponded to position 92 in the variant half. Thus, the $\mathrm{C}_{\mathrm{L}}{ }^{*}$ was 25 amino acid residues longer than the $\mathrm{C}_{\mathbf{L}}{ }^{\mathrm{P}}$ (Fig. 6).

Additional physicochemical studies were performed to compare the $\mathrm{C}_{\mathbf{L}}{ }^{*}$ and the $\mathrm{C}_{\mathrm{L}}{ }^{\mathrm{P}}$. The characteristic heat properties of the Bence Jones protein are known to be conferred by the $V_{L}$ (11); the additional 25 amino acid residues of the $C_{L} *$ extending into the $V_{L}$ were not sufficient to produce a detectable difference between the thermal solubility properties of the $C_{\mathbf{L}}{ }^{*}$ and the $C_{\mathbf{L}}{ }^{\mathbf{P}}$. In contrast to the Bence Jones protein and $\mathrm{V}_{\mathbf{L}}{ }^{\mathrm{P}}$ which precipitated at $56^{\circ} \mathrm{C}$, the $\mathrm{C}_{\mathrm{L}}{ }^{*}$ and $\mathrm{C}_{\mathrm{L}}{ }^{\mathrm{P}}$ remained soluble even with heating to $100^{\circ} \mathrm{C}$.

An antigenic site which is not immunochemically demonstrable in the native intact $\kappa$ light polypeptide chain has been detected in the unfolded light chain and localized to the $C_{L}{ }^{P}$ (23). The additional 25 residues in the $C_{\mathrm{L}}$ * were sufficient, however, to mask the

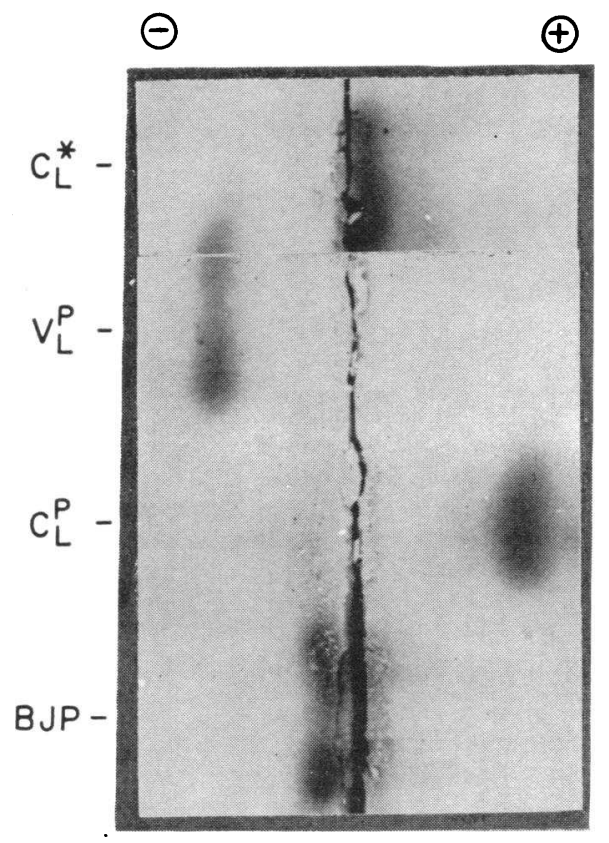

FIGURE 5 Alkaline-urea starch gel electropherogram of the Bence Jones protein (BJP), the new constant half-related component $\left(\mathrm{C}_{\mathrm{L}}^{*}\right)$ produced during the course of corticosteroid therapy, and the constant $\left(\mathrm{C}_{\mathrm{L}}{ }^{\mathrm{P}}\right)$ and variant $\left(\mathrm{V}_{\mathrm{L}}^{\mathrm{P}}\right)$ halves produced by limited peptic cleavage of the Bence Jones protein. Each protein was isolated and purified for comparison of electrophoretic mobilities.

hidden site. Treatment of the $\mathrm{C}_{\mathrm{L}}$ * with a dissociating solvent ( $8 \mathrm{M}$ urea) exposed the site.

The Inv antigenicity of a $\kappa$ light polypeptide chain is related to two genetic sites located at positions 153 and 191 in the constant region of the $\kappa$-chain molecule (24). The selective cleavage of a $\kappa$-chain into its constituent $V_{L}$ and $C_{L}$ results in a loss of Inv antigenicity (25). Samples of the isolated Bence Jones protein, $\mathrm{V}_{\mathbf{L}}{ }^{\mathbf{P}}, \mathrm{C}_{\mathbf{L}}{ }^{\mathbf{P}}$, and $\mathrm{C}_{\mathbf{L}}{ }^{*}$ were supplied to Dr. Arthur $\mathrm{G}$. Steinberg for Inv typing. The Bence Jones protein was $\operatorname{Inv}(3)$, and the $\mathrm{V}_{\mathbf{L}}{ }^{\mathrm{P}}$ and $\mathrm{C}_{\mathrm{L}}{ }^{\mathrm{P}}$ were devoid of Inv antigenicity. The $\mathrm{C}_{\mathrm{L}}$ * and Bence Jones protein were tested at equivalent protein concentration $(1 \mathrm{mg} / \mathrm{ml})$ for Inv(3) activity. The Inv(3) activity of the whole protein exceeded that expressed by the $\mathrm{C}_{\mathrm{L}} *$ by 32 -fold, i.e., the Bence Jones protein and the $\mathrm{C}_{\mathrm{L}}{ }^{*}$ possessed

$\mathrm{v} / \mathrm{C}$

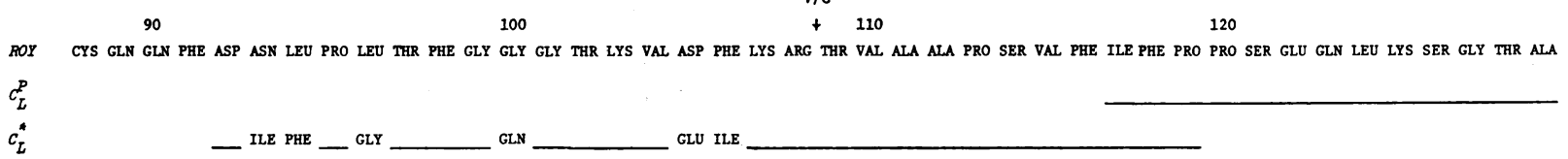
Figure 6 Amino acid sequence of the $C_{L}{ }^{P}$ and $C_{L}{ }^{*}$ fragments as compared to $\kappa I$ Bence Jones protein ROY (22). Only differences from protein ROY are indicated.

Corticosteroid-Associated Alteration in Bence Jones Proteins 


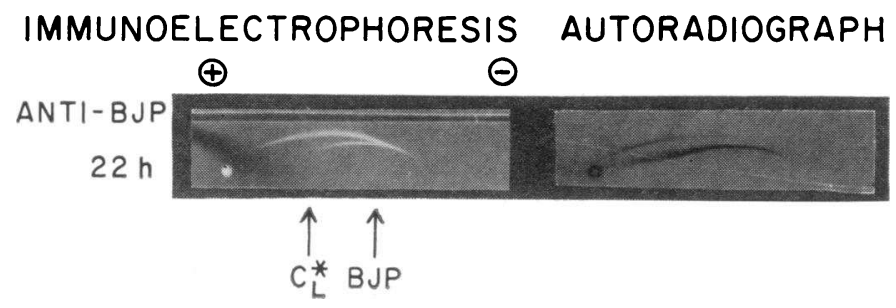

FIgURE 7 Identification of $\mathrm{C}_{\mathrm{L}} *$ and Bence Jones protein in culture fluid. (Left) Immunoelectrophoresis. The antigen well contained 22 -h culture fluid plus, as carrier protein, a urine specimen obtained at a time when the patient's urine contained both $\mathrm{C}_{\mathrm{L}}{ }^{*}$ and Bence Jones protein (BJP). The antiserum trough contained an antiserum prepared against the patient's Bence Jones protein. (Right) Autoradiograph. The autoradiogram was developed after 7 days exposure.

detectable Inv(3) activity at minimal concentrations of $0.004 \mathrm{mg} / \mathrm{ml}$ and $0.128 \mathrm{mg} / \mathrm{ml}$, respectively.

Biosynthetic studies were performed at a time when both $\mathrm{C}_{\mathrm{L}} *$ and Bence Jones protein were present in the urine. Tumor cells derived from the bone marrow were incubated in a growth medium containing ${ }^{14} \mathrm{C}$-labeled lysine and isoleucine and the extracellular culture fluid was harvested at timed intervals. The results of the immunoelectrophoretic and autoradiographic analyses of the $22 \mathrm{~h}$ culture fluid are shown in Fig. 7. The pattern of the autoradiogram gave exact correspondence to the two precipitin arcs obtained by immunoelectrophoresis; one arc corresponded to the $C_{\mathrm{L}} *$ and the other to the Bence Jones protein. Analyses of the extracellular culture fluid harvested at $5 \mathrm{~h}$ and $9 \mathrm{~h}$ also revealed the presence of ${ }^{14} \mathrm{C}$-labeled $\mathrm{C}_{\mathrm{L}} *$ and Bence Jones protein.

\section{DISCUSSION}

Myeloma proteins and Bence Jones proteins are biological markers of plasma cell tumors and provide a means for an objective evaluation of the response of the patient with multiple myeloma to therapy. Corticosteroids alone rarely have been effective in the treatment of multiple myeloma, however, corticosteroids have been found to enhance the effectiveness of cytotoxic chemotherapy as reflected by the decrease in the concentration of serum myeloma protein and Bence Jones protein (26-29).

While the general phenomenon of decrease in Bence Jones protein has been observed during treatment which includes corticosteroids, the daily changes have not been well documented. We obtained from six of our patients daily urine specimens before, during, and after treatment, and found that in five patients a marked but transient decrease in the concentration of Bence Jones protein occurred during the period of corticosteroid administration. Furthermore, the decrease in Bence Jones protein was associated in three patients with the transitory appearance of a new protein related to the Bence Jones protein and which disappeared with cessation of prednisone therapy. No association between light chain type ( $\kappa$ or $\lambda$ ) and response to therapy was evident. Analyses of urine specimens obtained daily from one patient over an extensive time period which included 10 treatment cycles revealed that this phenomenon was reproducible and was associated with prednisone and not with the cytotoxic chemotherapeutic agent(s). Isolation and characterization of this new component from the urine of three patients revealed it to be structurally and antigenically most related to the $C_{L}$, and hence, it was designed $C_{L} *$. Sequence analyses of the $\mathrm{C}_{\mathrm{L}}$ * isolated from the urine of one patient showed the $\mathrm{C}_{\mathrm{L}} *$ to be 25 amino acid residues longer than the $\mathrm{C}_{\mathrm{L}}{ }^{\mathrm{P}}$. These additional 25 residues were sufficient to mask the hidden antigenic site readily detectable in the $\mathrm{C}_{\mathrm{L}}{ }^{\mathrm{P}}$ (22), as well as to confer detectable Inv antigenicity to the $\mathrm{C}_{\mathrm{L}}{ }^{*}$. However, the $\mathrm{C}_{\mathrm{L}}{ }^{*}$ like the $\mathrm{C}_{\mathrm{L}}{ }^{\mathrm{P}}$ remained soluble upon heating to $100^{\circ} \mathrm{C}$ (11).

The amino-terminus of the $\mathrm{C}_{\mathrm{L}} *$ corresponded to position 92 in the variant region of the $\kappa$-chain (22). Low molecular weight proteins related to Bence Jones proteins have been found in urine specimens from patients with multiple myeloma $(1-6)$. These components were found only in the presence of whole Bence Jones protein, and were related to the $V_{L}$ but rarely to the $C_{L}$ of the intact protein. The presence of these components were not associated with therapy, and structural studies $(8,9)$ revealed that the fragments, which were related to the variant half of the light chain, were indeed identical to the $V_{\mathbf{L}}$, i.e., each had its carboxyl-terminus in the "switch" region between the $V_{L}$ and $C_{L}$ and appeared to be a catabolic product of the Bence Jones protein $(10,11)$. However, other observations have been indicative of a synthetic origin of $V_{L}$ or $C_{L}$ (11-15). Recently, chemical analyses of fibrillar protein from certain patients with amyloidosis 
have shown this material to consist of homogeneous immunoglobulin light chain, either $V_{L}$ or intact Bence Jones protein, and further that $\mathrm{V}_{\mathrm{L}}$ formed in vitro by peptic cleavage of certain Bence Jones proteins share physicochemical properties characteristic of amyloid fibrils (30). However, the patients reported in this study did not have amyloidosis, nor did the $\mathrm{V}_{\mathbf{L}}{ }^{\mathbf{P}}$ of their Bence Jones proteins have properties of amyloid.

The significance of the $C_{\mathrm{L}} *$ having its amino-terminus at position 92, which is the beginning of the third hypervariable region of the $V_{\mathbf{L}}(31)$, remains to be determined. Whether the $\mathrm{C}_{\mathrm{L}}{ }^{*}$ is of synthetic or catabolic origin is presently not known; however, the detection of the $\mathrm{C}_{\mathrm{L}}{ }^{*}$ and the absence of any detectable protein related to the $V_{L}$ in the extracellular culture fluid might imply a synthetic origin of the $\mathrm{C}_{\mathrm{L}} *$ and suggest a corticosteroid-induced alteration in light chain synthesis. ${ }^{2}$

Corticosteroids are known to interfere with protein synthesis and to suppress both cell-mediated and humoral immune responses. Studies by Butler, Rosen, Couch, and Hersh $(32,33)$ have shown that high doses of the corticosteroid methylprednisolone given to normal volunteers for 3 or 5 days caused a pronounced and sustained decrease in serum IgG concentration. The effect was attributed to suppression of ongoing immunoglobulin and antibody synthesis since no inhibition of primary and secondary antibody responses was observed; that is, the primary effect of corticosteroids was not on cells involved in the induction of the immune response, but was on the plasma cell or plasma cell precursor. It is of obvious interest to determine whether the effects of corticosteroids on Bence Jones proteinuria observed in our patients with multiple myeloma result from the same mechanism responsible for decrease in IgG in normal individuals. Detailed measurements of the serum concentration of normal immunoglobulins or myeloma proteins, where present, were not possible due to the relatively small number of serum specimens obtained. Although we observed the phenomenon of marked decrease in Bence Jones protein in five of six patients treated with prednisone and the concomitant appearance of $\mathrm{C}_{\mathrm{L}} *$ in three of the five patients, the absence of this phenomenon in one patient similarly treated generates questions concerning whether the effect of corticosteroids is dependent upon specific properties of the plasma cell or of the light chain. Biosynthetic studies are currently in progress to investigate these factors.

${ }^{2}$ The lack of antiserum specific for $C_{L}{ }^{*}$ precluded its identification in serum specimens. Neither the $C_{L} *$ nor the $\mathrm{C}_{\mathrm{L}}{ }^{\mathrm{P}}$ was detected after incubation at $37^{\circ} \mathrm{C}$ for $24 \mathrm{~h}$ of Bence Jones protein in a phosphate-buffered saline solution, $\mathrm{pH}$ 7.4, which contained prednisone at a concentration of 5 $\mathrm{mg} / \mathrm{ml}$.

\section{ACKNOWLEDGMENTS}

The authors wish to thank Dr. Arthur G. Steinberg for Inv typing of our proteins.

This investigation was supported by USPHS Research Grant CA 10056-09 from the National Cancer Institute (A. S., C. L. McL.), Research Grant AI 12127 from the National Institute of Allergy and Infectious Diseases, and Grant GB 41530X from the National Science Foundation (J. D. C.).

\section{REFERENCES}

1. Deutsch, H. F. 1963. Crystalline low molecular weight $\gamma$-globulin from a human urine. Science (Wash. D. C.). 141: 435-436.

2. Solomon, A., J. Killander, H. M. Grey, and H. G. Kunkel. 1966. Low-molecular weight proteins related to Bence Jones proteins in multiple myeloma. Science (Wash. D. C.). 151: 1237-1239.

3. Williams, R. C., Jr., S. R. Pinnel, and G. T. Bratt. 1966. Low molecular weight L-chain components related to Bence-Jones proteins. J. Lab. Clin. Med. 68 : 81-89.

4. Cioli, D., and C. Baglioni. 1966. Origin of structural variation in Bence-Jones proteins. J. Mol. Biol. 15 : $385-388+2$ plates.

5. Tan, M., and W. Epstein. 1967. Antigenic analysis of an N-terminal fragment of a type $\kappa$ Bence Jones protein. J. Immunol. 98: 568-575.

6. Van Eyk, H. G., and K. Myszkowska. 1967. On the localization of antigenic determinants in a Bence Jones protein. Clin. Chim. Acta. 18: 101-106.

7. Berggård, I., and P. Peterson. 1967. Immunoglobulin components in normal human urine. In Gamma Globulins, Nobel Symposium 3. J. Killander, editor. Almqvist and Wiksell, Publishers, Stockholm. 71-80.

8. Deutsch, H. F. 1965. Relationships of two light chain immunoglobulins isolated from the same human source (low molecular weight immunoglobulins). Immunochemistry. 2 : 207-218.

9. Baglioni, C., D. Cioli, G. Gorini, A. Ruffilli, and L. Alescio-Zonta. 1967. Studies on fragments of light chains of human immunoglobulins: genetic and biochemical implications. Cold Spring Harbor Symp. Quant. Biol. 32 : 147-159.

10. Cioli, D., and C. Baglioni. 1968. Catabolic origin of a Bence Jones protein fragment. J. Exp. Med. 128: 517532 .

11. Solmon, A., and C. L. McLaughlin. 1969. Bence-Jones proteins and light chains of immunoglobulins. I. Formation and characterization of amino-terminal (variant) and carboxyl-terminal (constant) halves. J. Biol. Chem. 244 : 3393-3404.

12. Cioli, D., and C. Baglioni. 1967. Studies on the synthesis of the peptide chains of human immunoglobulins. In Gamma Globulins, Nobel Symposium 3. J. Killander, editor. Almqvist and Wiksell, Publishers, Stockholm. $401-420$.

13. Schubert, D., and M. Cohn. 1970. Immunoglobulin biosynthesis. V. Light chain assembly. J. Mol. Biol. 53: 305-320.

14. Kuehl, W. M., and M. D. Scharff. 1974. Synthesis of a constant region light chain fragment by the MPC-11 mouse myeloma cell line. Fed. Proc. 33: 725. (Abstr.)

15. Matsuoka, Y., Y. Yagi, G. E. Moore, and D. Pressman. 1969. Isolation and characterization of a free $\lambda$ chain of immunoglobulin produced by an established 
cell line of human myeloma cell origin. J. Immunol. 103: 962-969.

16. Lowry, O. H., N. J. Rosebrough, A. L. Farr, and R. J. Randall. 1951. Protein measurement with the Folin phenol reagent. J. Biol. Chem. 193: 265-275.

17. Kunkel, H. G. 1954. Zone electrophoresis. Methods Biochem. Anal. 1: 141-170.

18. Solomon, A., and C. L. McLaughlin. 1969. Bence Jones proteins and light chains of immunoglobulins. II. Immunochemical differentiation and classification of kappachains. J. Exp. Med. 130: 1295-1311.

19. Poulik, M. D. 1966. Gel electrophoresis in buffers containing urea. Methods Biochem. Anal. 14: 455-495.

20. Capra, J. D., J. M. Kehoe, R. C. Williams, Jr., T. Feizi, and H. G. Kunkel. 1972. Light chain sequences of human IgM cold agglutinins. Proc. Natl. Acad. Sci. U. S. A. 69 : $40-43$.

21. Seon, B. K., A. L. Grossberg, O. A. Roholt, and D. Pressman. 1973. Position of the selective peptic cleavage of human $\kappa$-chain between the $\mathrm{V}$ and $\mathrm{C}$ domains. J. Immunol. 111: 269-271.

22. Dayhoff, M. O., editor. 1972. In Atlas of Protein Sequence and Structure. National Biomedical Research Foundation, Washington, D. C. Vol. 2.

23. McLaughlin, C. L., and A. Solomon. 1973. A hidden antigenic site localized to the constant region of light chains of immunoglobulins. Science (Wash. D. C.). 179: $580-582$.

24. Milstein, C. P., A. G. Steinberg, C. L. McLaughlin, and A. Solomon. 1974. Amino acid sequence change associated with genetic marker Inv(2) of human immunoglobulin. Nature (Lond.). 248: 160-161.

25. Solomon, A., C. L. McLaughlin, and A. G. Steinberg. 1970. Bence Jones proteins and light chains of immunoglabulins. III. Inv antigenicity: a genetic expression with serologic dependency on the intact kappa light chain molecule. Immunochemistry. 7: 709-713.

26. Caggiano, V., J. Cuttner, and A. Solomon. 1967. Myeloma proteins, Bence Jones proteins, and normal immunoglobulins in multiple myeloma. Blood J. Hematol. $30: 265-287$.

27. Alexanian, R., A. Haut, A. U. Khan, M. Lane, E. M. McKelvey, P. J. Migliori, W. J. Stuckey, Jr., and H. E. Wilson. 1969. Treatment for multiple myeloma. Jama J. Am. Med. Assoc. 208: 1680-1685.

28. Costa, G., R. L. Engle, Jr., A. Schilling, P. Carbone, S. Kochwa, R. L. Nachman, and O. Glidwell. 1973. Melphalan and prednisone: an effective combination for the treatment of multiple myeloma. Am. J. Med. 54: 589-599.

29. Solomon, A., and C. L. McLaughlin. 1973. Immunoglobulin disturbances and their clinical significance. Med. Clin. North Am. 57: 499-516.

30. Glenner, G. G., W. D. Terry, and C. Isersky. 1973. Amyloidosis: its nature and pathogenesis. Semin. Hematol. 10 : 65-86.

31. Wu, T. T., and E. A. Kabat. 1970. An analysis of the sequences of the variable regions of Bence Jones proteins and myeloma light chains and their implications for antibody complementarity. J. Exp. Med. 132: 211250.

32. Butler, W. T., and R. D. Rosen. 1973. Effects of corticosteroids on immunity in man. I. Decreased serum IgG concentration caused by 3 or 5 days of high doses of methylprednisolone. J. Clin. Invest. 52: 2629-2640.

33. Butler, W. T., R. B. Couch, R. D. Rosen, and E. M. Hersh. 1974. Methylprednisolone fails to inhibit primary and secondary antibody responses but causes marked suppression of on-going antibody formation in man. $J$. Clin. Invest. 53: 14a. (Abstr.) 